\title{
ETNOBOTANI TUMBUHAN SUMBER PANGAN MASYARAKAT DAYAK BIDAYUH DI DESA HLI BUEI KECAMATAN SIDING KABUPATEN BENGKAYANG
}

\author{
(Plant Food Ethnobotany of Dayak Bidayuh Community at Hli Buei Village Siding Subdistrict \\ Bengkayang District)
}

\author{
Lusiana Julia, H.A Oramahi, Gusti Hardiansyah \\ Fakultas Kehutanan Universitas Tanjungpura Pontianak. Jl. Daya Nasional Pontianak 78124 \\ E-mail : lusianajulia1396@gmail.com
}

\begin{abstract}
Abstrak
Food plants have long been used by local people of Hli Buei Village, Siding Subdistrict, Bengkayang District because of their simple processing and available in the forest. For generations, the village community has been accustomed to using food sources for their daily staple food needs. In addition, local food plants are still widely used because there is no market in Hli Buei Village. Until now, the use of plant food sources in Hli Buei Village, Siding Subdistrict, Bengkayang District has never been studied. Therefore, it is necessary to conduct research on the Ethnobotany of Plant Food for the Dayak Bidayuh Community in Hli Buei Village, Siding Subdistrict, Bengkayang District. The aim is to provide information about food plant species, utilization and processing of food source plants in Hli Buei Village, Siding Subdistrict, Bengkayang District. The research method is a survey method and data collection techniques by interview. Determination of respondents by purposive sampling in addition to observation and study of literature. Based on the results of interviews that have been conducted, there were 95 species from 44 families. The level of plant habitus that is widely used comes from the tree level (29.47\%), herbs (28.42\%), shrubs (22.1\%), and the least is epiphyte $(1.05 \%)$. The most part of the mash which used as food of the fruit, namely as many as 55 species (57.89\%), leaves 17 species (17.89\%) and the lowest was in the stems, shoots, tubers, flower buds, skin, fruit and heart, fruit. and umbut, fruit, tuber and water, terrace stem and tuber each 1 type (1.05\%). Utilization of the most food plant groups came from the fruit group, namely 36 species (37.89\%) and the lowest was the 3 species of cereals (3.15\%).
\end{abstract}

Keywords: Ethnobotany, Plant Food, Dayak Bidayuh

\section{PENDAHULUAN}

Indonesia dikenal sebagai negara agraris yang berarti negara yang mengendalikan sektor pertanian baik sebagai sumber mata pencaharian masyarakat maupun sebagai sektor penopang pembangunan (Saragih, 2001). Hutan merupakan salah satu sumberdaya alam yang besar peranannya dalam berbagai aspek kehidupan baik aspek ekonomi, sosial, pembangunan, dan lingkungan. Etnobotani merupakan kajian mengenai interaksi antara masyarakat lokal dengan lingkungan alamnya, terutama mengenai penggunaan tumbuhan dalam kehidupan sehari-hari (Martin, 1998).

Tumbuhan pangan adalah segala sesuatu yang tumbuh, hidup, berbatang, berakar, berdaun, dan dapat dimakan atau dikonsumsi oleh manusia. Bahan pangan yang dimaksud adalah makanan pokok, 
tumbuhan, minuman, bumbu masakan, dan rempah-rempah (Saepuddin, 2005). Pangan diartikan sebagai segala sesuatu yang bersumber dari hayati dan air, baik yang diolah maupun tidak diolah. Pangan diperuntukkan bagi konsumsi manusia sebagai makanan atau minuman, termasuk bahan tambahan pangan, bahan baku pangan dan bahan-bahan lain yang digunakan dalam proses penyiapan, pengolahan atau pembuatan makanan atau minuman.

Pemanfaatan tumbuhan bahan pangan secara langsung maupun tidak langsung mempunyai kaitan dalam upaya pelestarian dan pemanfaatan sumberdaya alam hayati. Kaidah tersebut dapat dilihat dari nilai-nilai yang terkandung dalam aturan adat dan pemanfaatan sumberdaya alam hayati yang dijumpai pada masyarakat asli suatu suku. Hasil penelitian terdahulu menyebutkan bahwa di Kalimantan Barat banyak ditemukan jenis-jenis tumbuhan pangan yang dapat dimanfaatkan, seperti pemanfaatan 47 jenis tumbuhan sumber pangan oleh masyarakat Desa Pangkalan Buton Kecamatan Sukadana Kabupaten Kayong Utara (Juliana, 2013). Berdasarkan hasil wawancara yang dilakukan, diketahui terdapat 43 jenis dari 26 famili tumbuhan yang dimanfaatkan sebagai sumber pangan oleh Suku Dayak Kanayatn di Desa Pak Mayam Kecamatan Ngabang Kabupaten Landak. Beberapa jenis tumbuhan yang dimanfatkan adalah kucai (Allium odorum L.), sirsak (Annona nuricata L.), sirsak kerikil (A. glabra L), asam (Mangifera foetida Lour), kedondong (Spondias dulcis Forst), rotan saga (Calamus caesius), kelapa (Cocos nucifera L.) (Nurhajijah, 2017). Berdasarkan hasil wawancara yang dilakukan terdapat 92 jenis dan 45 famili tumbuhan yang bisa dimanfaatkan sebagai sumber pangan oleh masyarakat sekitar Hutan Tembawang Desa Nanga Kompi Kecamatan Nanga Sayan Kabupaten Melawi. Famili yang terbanyak adalah Arecaceae dan Anacardiaceae 6 spesies, Cucubitaceae, Moraceae, Poaceae dan Solanaceae 5 spesies, Fabaceae, Musaceae, Myrtaceae dan Phyllanthaceae 4 spesies. Tumbuhan yang banyak dimanfaatkan masyarakat Desa Nanga Kompi diantaranya labu air (Lagenaria siceraria), labu kuning (Cucurbita mixta), padi (Oryza sativa L.), rebong bambu (Dendrocalamus asper), kangkung (Iponea aquatica), kabak (Pithecolobium lobatum), bawang (Allium sativum L.), paku (Pletycenum sp) (Dasman, 2015). Tumbuhan berpotensi bahan pangan di Desa Sebangun Kecamatan Sebawi Kabupaten Sambas yang diperoleh dari hasil penelitian berjumlah 33 jenis termasuk dalam 24 famili. Beberapa jenis tumbuhan yang dimanfaatkan adalah midding (Stenochlaena palustris), lapok (Passiflora foetida), paku uban (Nephrolepis biserrata), temurawe (Curcuma zedoari), pegage (Centtela asiatica), engkudu (Morinda citrifolia), singkil (Premna cordifolia), kesum (Polygonum odoratum), serta simpur (Dillenia suffruticosa) (Nurhidayah, 2015).

Tumbuhan bahan pangan telah lama dimanfaatkan masyarakat Desa Hli Buei Kecamatan Siding Kabupaten Bengkayang karena pengolahannya yang sederhana dan ketersediaannya cukup 
banyak didalam hutan. Sejak dulu secara turun-temurun masyarakat desa terbiasa memanfaatkan sumber-sumber pangan untuk memenuhi kebutuhan pangan pokok sehari-hari. Tumbuhan pangan lokal masih banyak dimanfaatkan karena di Desa Hli Buei tidak ada pasar. Pemanfaatan tumbuhan sumber pangan di Desa Hli Buei Kecamatan Siding Kabupaten Bengkayang sampai saat ini belum pernah diteliti. Oleh karena itu perlu dilakukan penelitian tentang Etnobotani Tumbuhan Sumber Bahan Pangan Msayarakat Dayak Bidayuh di Desa Hli Buei Kecamatan Siding Kabupaten Bengkayang sebagai langkah awal untuk memberikan informasi kepada masyarakat mengenai jenis dan cara pemanfaatannya. Tujuan penelitian adalah 1) Mendokumentasikan jenis-jenis dan bagian-bagian tumbuhan yang dimanfaatkan sebagai bahan pangan oleh masyarakat Dayak Bidayuh di Desa Hli Buei Kecamatan Siding Kabupaten Bengkayang, 2) Mengetahui manfaat dan cara pengolahan tumbuhan yang dimanfaatkan sebagai bahan pangan oleh masyarakat di Desa Hli Buei Kecamatan Siding Kabupaten Bengkayang.

\section{METODE}

Penelitian ini dilaksanakan di Desa Hli Buei Kecamatan Siding Kabupaten Bengkayang dalam jangka waktu 1 bulan efektif di lapangan dari tanggal 15 Juni sampai 14 Juli 2019. Metode yang digunakan dalam penelitian ini adalah metode survei, penentuan responden menggunakan purposive sampling dengan teknik wawancara, observasi, dan studi literatur. Menurut sugiyono (2014) purposive sampling adalah teknik pengambilan sampel sumber data yang didasarkan dengan pertimbangan tertentu. Pertimbangan tertentu yang dimaksudkan adalah sampel atau orang yang dianggap paling tahu tentang apa yang diharapkan atau mungkin orang yang menguasai sehingga akan memudahkan peneliti menjelajahi obyek/situasi sosial yang diteliti. Kriteria informan yang digunakan dalam penelitian ini yaitu merupakan warga asli desa hli buei yang memiliki pengetahuan luas mengenai nama lokal tumbuhan bahan pangan dan mendapatkan informasi yang dicari tentang pemanfaatan tumbuhan bahan pangan seperti petani dan ibu rumah tangga yang usianya mencapai 50 tahun serta informan merupakan masyarakat yang tinggal di Desa Hli Buei lebih dari 10 tahun dan dalam kesehariannya menggunakan tumbuhan bahan pangan.

\section{HASIL DAN PEMBAHASAN}

Pemanfaatan Tumbuhan Sumber Pangan Oleh Masyarakat Desa Hli Buei

Berdasarkan hasil wawancara dengan masyarakat di sekitar hutan Desa Hli Buei tumbuhan sumber pangan diperoleh sebanyak 95 jenis tumbuhan dari 44 famili tumbuhan sumber pangan yang biasa dimanfaatkan oleh masyarakat Desa Hli Buei sebagai sumber pangan (terlampir).

\section{Famili Tumbuhan Sumber Pangan}

Berdasarkan hasil wawancara dengan masyarakat di Desa Hli Buei diperoleh sebanyak 95 jenis dan 45 famili tumbuhan yang biasa dimanfaatkan oleh masyarakat sebagai tumbuhan sumber pangan dapat dilihat pada Gambar 1. 


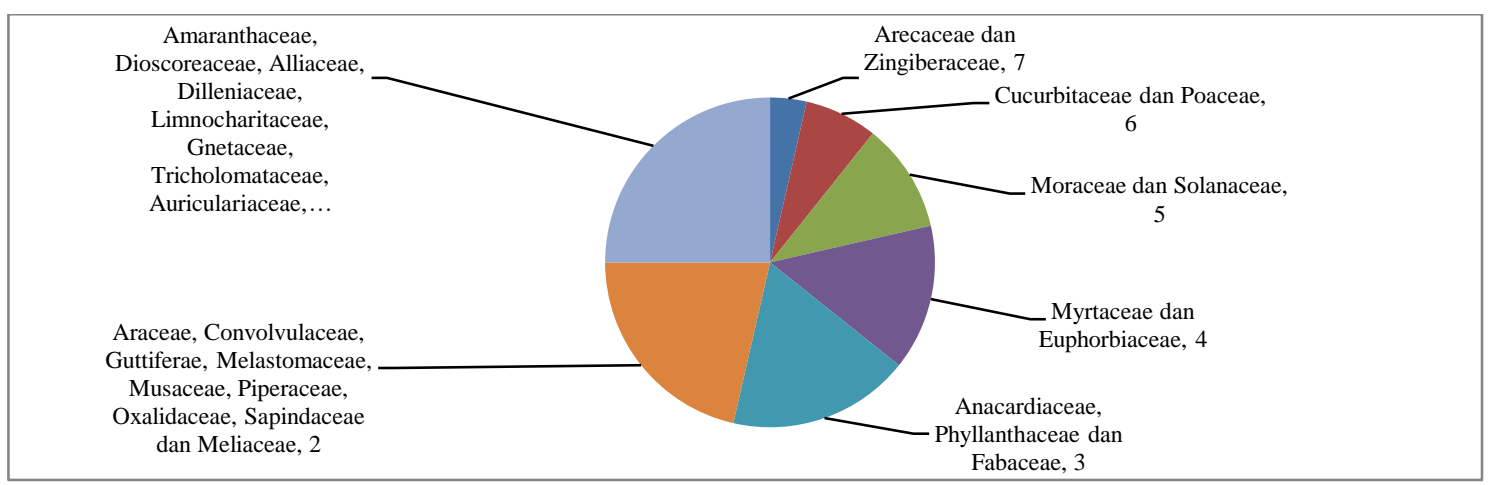

Gambar 1. Dominasi Famili Tumbuhan Sumber Pangan (Family Domination of Food Sources Plant)

Tumbuhan sumber pangan sebanyak 45 famili ditemukan pada penelitian ini, ada berberapa famili yang mendominasi antara lain famili Arecacea dan Zingiberacea masing-masing 7 jenis, Cucurbitaceae dan Poaceae masingmasing 6 jenis, Moraceae dan Solanaceae masing-masing 5 jenis, Euphorbiaceae dan Myrtaceae masing-masing 4 jenis, Anacardiaceae, Phyllanthaceae dan Fabaceae masing-masing 3 jenis, Aracea, Convolvulaceae,

Guttiferae,

Melastomaceae, Musaceae, Piperaceae, Oxalidaceae, Sapindaceae, dan Meliaceae masing-masing 2 jenis, Amaranthaceae, Dioscoreaceae, Alliaceae, Dilleniaceae,
Limnocharitaceae,

Gnetaceae, Tricholomataceae, Auriculariaceae, Sterculiaceae, Dipterocarpaceae, Rubiaceae, Bombacaceae, Rutaceae, Anonnaceae, Bromeliaceae, Lamiaceae, Aspleniaceae, Caricaceae, Denstaediticeae, Athyriaceae, Polypodiaceae, Brassicaceae, Manispermaceae dan Leguminaceae masing-masing 1 jenis. Jenis tumbuhan tersebut banyak diperoleh di hutan (42 jenis) dan perkarangan (19 jenis).

Habitat tumbuhan sumber pangan yang dimanfaatkan oleh masyarakat Dayak Bidayuh Desa Hli Buei disajikan pada Gambar 2.

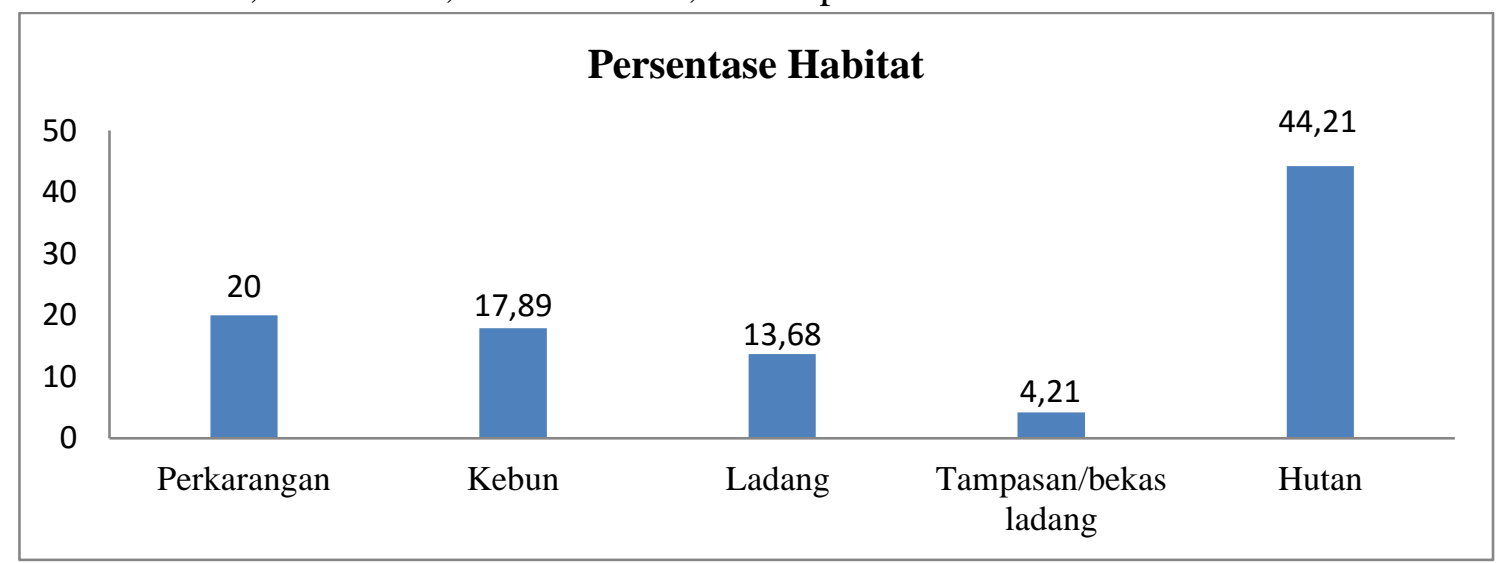

Gambar 2. Persentase Habitat tumbuhan sumber pangan masyarakat dayak bidayuh di Desa hli buei (Percentage of Food Source Plant Habitat for Dayak Bidayuh Community in Hli Buei Village) 


\section{Bagian Yang Digunakan Dan Cara Pengolahan Tumbuhan Sumber Pangan}

Berdasarkan dari hasil wawancara dengan masyarakat di Desa Hli Buei, bagian tumbuhan yang digunakan sebagai bahan pangan oleh masyarakat sangat bervariasi, mulai dari bagian buah, daun, umbut, umbi, jantung, seluruh bagian dari tumbuhan, tunas muda dan batang. Persentase tumbuhan berdasarkan bagian yang digunakan sebagai pangan dapat dilihat pada Gambar 3.

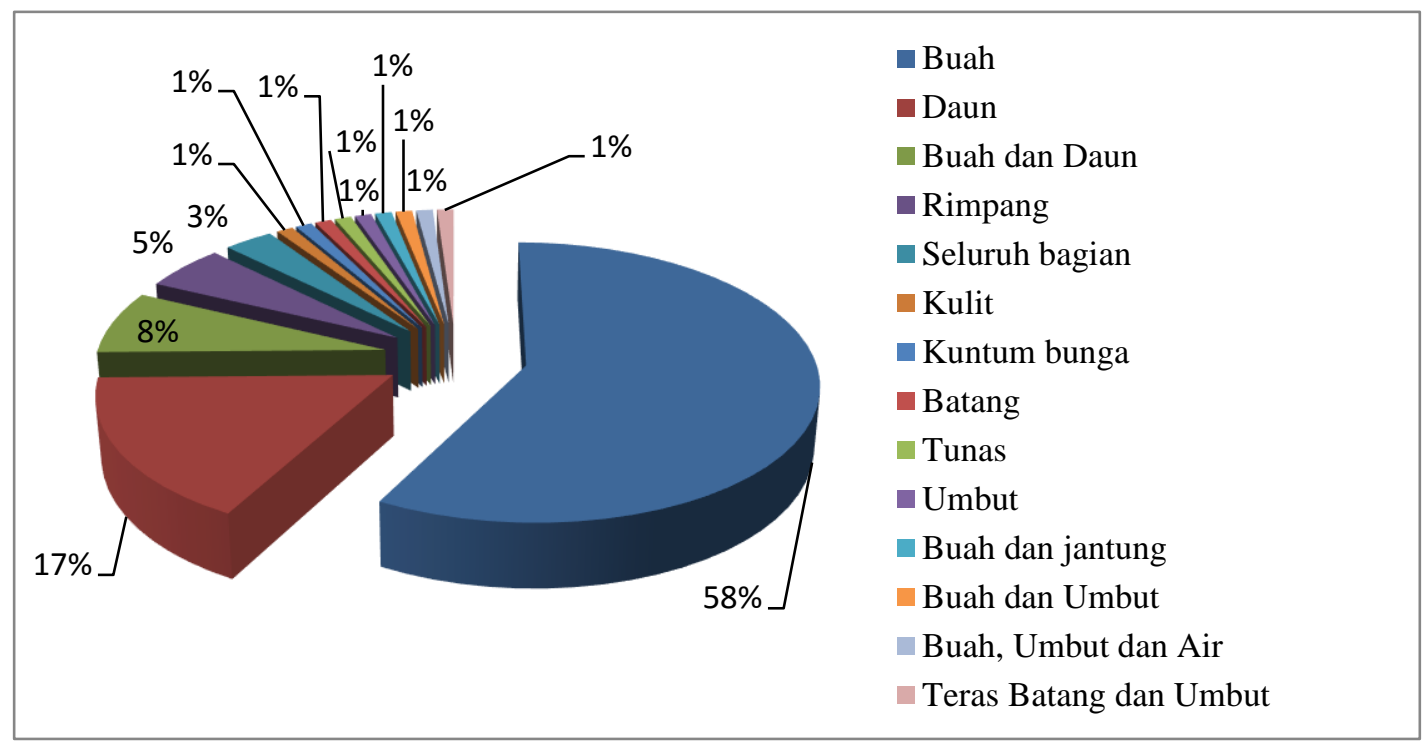

Gambar 3. Bagian Tumbuhan yang Digunakan Sebagai Pangan (Parts of Plants Used as Food)

Bagian tumbuhan terbanyak yang digunakan sebagai pangan adalah bagian buah yaitu sebanyak 55 jenis $(57,89 \%)$, daun 17 jenis $(17,89 \%)$ dan terendah pada bagian batang, tunas, umbut, kuntum bunga, kulit, buah dan jantung, buah dan umbut, buah, umbut dan air, teras batang dan umbut masing-masing 1 jenis $(1,05 \%)$. Seperti penelitian yang lainnya tentang tumbuhan pangan buah-buahan merupakan bagian tumbuhan yang paling banyak digunakan. Bagian buah yang digunakan sebagai tumbuhan pangan seperti asom bawang (Mangifera pajang), dungon (Baccaurea macrocarpa) dan buduak (Artocarpus integer (Thunb). Mer). Hasil penelitian serupa juga ditemukan pada penelitian Tatang $d k k$. (2000), di Desa Tanggerang Kecamatan Jelai Hulu Kabupaten Ketapang dimana bagaian buah merupakan bagian tumbuhan yang paling banyak digunakan sebagai tumbuhan pangan. Kemudian pada penelitian Sunarti $d k k$. (2007), di Cagar Alam Tangale Kecamatan Tibawa Provinsi Gorontalo juga menunjukkan bahwa bagian tumbuhan yang paling banyak digunakan adalah bagian buahbuahan.

Berdasarkan hasil penelitian tumbuhan sumber pangan yang dimanfaatkan masyarakat di Desa Hli Buei Kecamatan Siding Kabupaten Bengkayang, masyarakat mengolah tumbuhan sangat beragam biasanya dengan cara dimasak (40 jenis), 
dikonsumsi langsung (39 jenis), dimasak dan dikonsumsi langsung (16 jenis), seperti Lieai (Durio zibethinus Murr) buah yang sudah masak dapat dikonsumsi langsung dan dapat pula dijadiakan berbagai makanan olahan seperti tempoyak dan bubur durian. Mhun (Cucumis sp) buah muda dapat dimakan langsung dan daun muda dapat dimakan langsung dengan cara diremasremas dicampur dengan cabai atau sambal dapat juga dimasak dijadikan sayur. Naka (Artocarpus heterophyllus Lamk) buah masak dapat langsung dimakan, buah muda dapat dijadikan sayuran, biji buah masak dapat direbus dijadikan sebagai cemilan.

Cara pengolahan tumbuhan sumber pangan terbanyak adalah dengan cara dimasak yaitu $42 \%$. Adapun persentase jenis tumuhan berdasarkan cara pengolahan dapat dilihat pada Gambar 4.

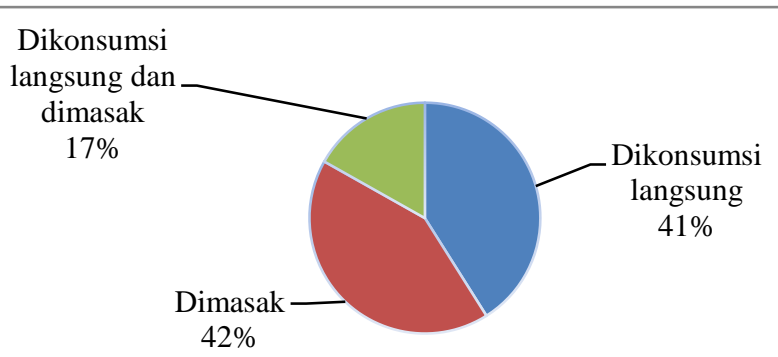

Gambar 4. Cara Pengolahan Tumbuhan Sumber Pangan (Process of Food Source Plant)

\section{Habitus Tumbuhan Sumber Pangan}

Berdasarkan hasil dilapangan ditemukan 95 jenis tumbuhan sumber pangan yang terdiri dari tingkat pohon, perdu, palem, terna, herba, liana, epifit. Adapun jumlah tumbuhan pangan berdasarkan habitus dapat dilihat pada Gambar 5.

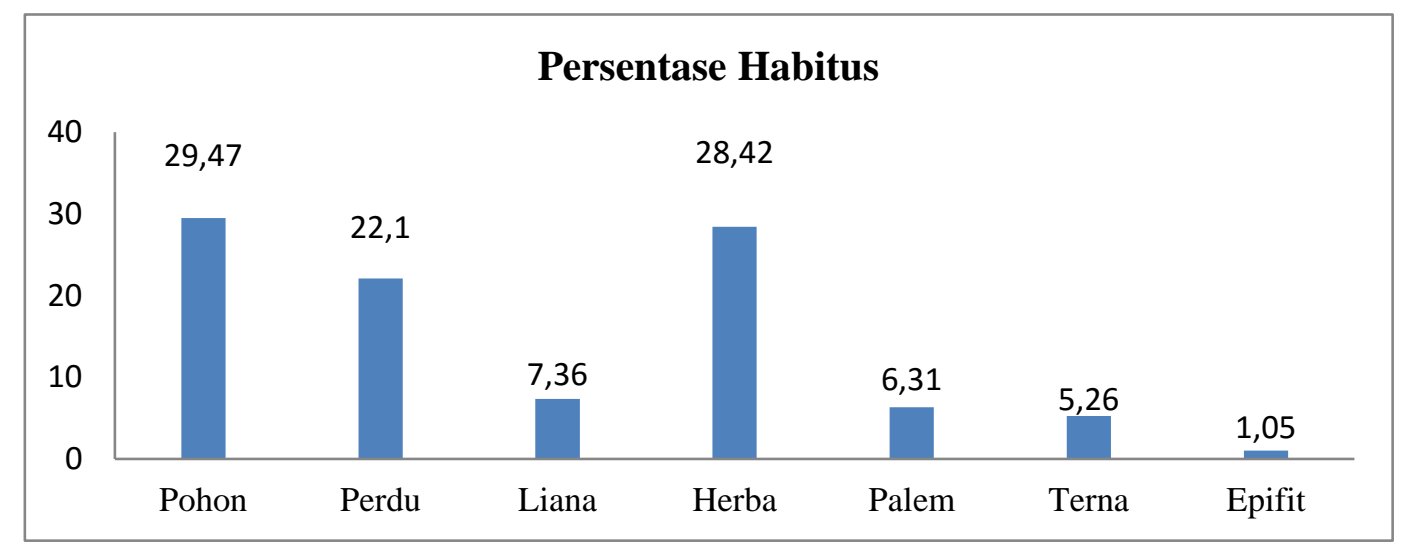

Gambar 5. Habitus Tumbuhan Sumber Pangan yang Dimanfaatkan Oleh Masyarakat Dayak Bidayuh di Desa Hli Buei (Plant Habitus as Food Source Used by The Dayak Bidayuh Community in the Hli Buei Village) 
Habitus atau ciri-ciri umum tumbuhan sumber pangan yang ditemukan dalam penelitian ini sangat bervariasi, mulai dari tumbuhan berhabitus pohon (28 jenis) seperti taop (Artocarpus elasticus Reinw. ex BI), lieai (Durio zibethinus Murr), dan kinih (Gracinia xanthochymus Miq), perdu (21 jenis) seperti buan't (Dillenia suffruticosa) dan naka bhane (Anonna muricata L), terna (5 jenis) seperti duk (Colocasia esculanta L), herba (27 jenis) seperti milieam (Capsium frutescens) dan pikuh (Diplazium esculentum), liana (7 jenis) seperti litak mhu (Vigna unguiculata sesquipedalis), epifit 1 jenis yaitu pap (Asplenium nidus L). Habitus yang paling banyak ditemui adalah pohon yaitu $29,47 \%$ dan yang terendah adalah epifit yaitu (1,05\%). Hasil pengamatan dilapangan diperoleh jenis tumbuhan sumber pangan yang banyak ditemukan berupa tumbuhan berkayu yaitu tingkat pohon. Hasil yang sama didapatkan pada penelitian di Desa Nanga Kompi Kecamatan Nanga Sayan Kabupaten Melawi dimana lebih banyak ditemukan tumbuhan tingkat pohon.

Kelompok Tumbuhan Sumber Pangan

Jenis-jenis tumbuhan yang dimanfaatkan oleh masyarakat Desa Hli Buei sebagai pangan terdiri dari kelompok buah-buahan seperti lamut (Nephelium lappaceum L) dan blumingk (Baccaurea angulata), kelompok sayur-sayuran seperti bayam (Amaranthus sp), manis (Sauropus androgynus) dan pikies (Stenochlena polustris), kelompok minuman seperti dan't (Cocos nucifera), kelompok karbohidrat seperti pidiei (Oryza sativa L) dan kliea (Ipomea batatas L), kelompok sereal seperti gliei (Ciox lacryma-jobi L). Pemanfaatan yang paling banyak berasal dari kelompok buah-buahan yaitu 36 jenis (37,89\%) dan yang terendah adalah kelompok sereal 3 jenis $(3,15 \%)$. Persentase jenis tumbuhan berdasarkan kelompok pangan secara lengkap dapat dilihat pada Gambar 6.

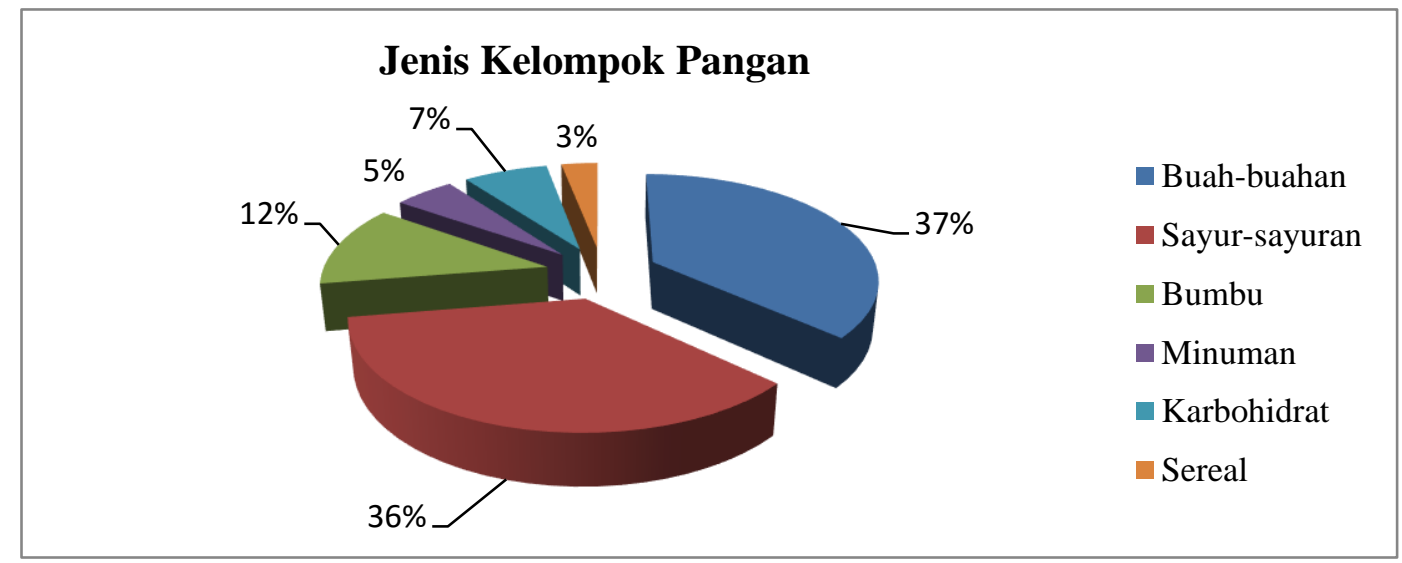

Gambar 6. Jenis Kelompok Tumuhan Sumber Pangan yang Dimanfaatkan Oleh Masyarakat Dayak Bidayuh di Desa Hli Buei (Group of Plant Species as Food Source Used by Dayak Bidayuh Community in Hli Buei Village) 


\section{Tumbuhan Untuk Kegunaan Adat}

Berdasarkan hasil wawancara dengan masyarakat di Desa Hli Buei, ada beberapa dari tumbuhan digunakan sebagai tumbuhuan untuk kegunaan adat oleh masyarakat di Desa Hli Buei. Jenis tumbuhan tersebut dapat dilihat pada Tabel 2.

Tabel 2. Daftar Tumbuhan yang Digunakan Untuk Kegunaan Adat (Plant Used For Customary)

\begin{tabular}{|c|c|c|c|c|}
\hline No & $\begin{array}{l}\text { Nama } \\
\text { Lokal }\end{array}$ & Nama Ilmiah & Famili & Kegunaan Adat \\
\hline 1 & 2 & 3 & 4 & 5 \\
\hline 1 & Dan't & Cocos nucifera $\mathrm{L}$ & Arecaceae & Permandian \\
\hline 2 & Baai & Areca catechu $\mathrm{L}$ & Arecaceae & Pernikahan \\
\hline 3 & Bieid & Piper betle & Piperaceae & $\begin{array}{l}\text { Pernikahan, pengobatan, } \\
\text { kematian }\end{array}$ \\
\hline 4 & Bilak & Musa paradisiaca & Musaceae & Buang-buang \\
\hline 5 & Bluk & Bambusa sp & Poaceae & Sukuran \\
\hline 6 & Buan't & Dillenia suffruticosa & Dilleniaceae & Buang-buang \\
\hline 7 & Gamel & Uncaria Gambir Roxb & Rubiaceae & $\begin{array}{l}\text { Pernikahan, pengobatan, } \\
\text { kematian }\end{array}$ \\
\hline 8 & Pidiei & Oryza sativa $\mathrm{L}$ & Poaceae & Permohonan maaf \\
\hline 9 & Pungiat & Cordyline fruticosa (L) A.Chev & Asparagaceae & Buang-buang \\
\hline 10 & Timuk & Curcuma domestica & Zingiberaceae & Buang-buang \\
\hline
\end{tabular}

Sumber : Analisis Data dan Wawancara (2019)

Kegiatan pelaksanaan upacara adat sekitar Desa Hli Buei ini memanfaatkan beberapa dari spesies tumbuhan. Hasil dari wawancara menunjukan bahwa sebagian besar peralatan dan bahan dalam upacara adat didominasi oleh tumbuhan sebanyak 10 spesies tumbuhan dari 8 famili yang digunakan dalam upacara adat (tabel 2). Famili terbanyak yaitu famili Poaceae dan Arecaceae masing-masing 2 spesies, Piperaceae, Musaceae, Dilleniaceae, Rubiaceae, Asparagaceae dan Zingiberaceae masing-masing 1 spesies.

Berdasarkan hasil penelitan telah diketahui bahwa penelitian Haryanti, dkk. (2015), di Desa Tamao Kecamatan Embaloh Hulu Kabupaten Kapuas Hulu terdapat lebih banyak 58 spesies tumbuhan adat dibandingkan di Desa Hli Buei Kecamatan Siding Kabupaten Bengkayang hal ini dikarenakan adanya perbedaan masyarakat dalam pemanfaatan tumbuhan untuk kegunaan upacara adat disetiap daerah masingmasing.

Penggunaan sejumlah spesies tumbuhan dalam rangkaian upacara adat melambangkan adanya hubungan antara manusia dengan alam sekitarnya. Selain itu tumbuhan yang sering dimanfaatkan untuk keperluan adat biasanya akan lebih dipelihara oleh masyarakat. Spesies yang tadinya liar biasanya akan dibudidayakan karena akan lebih mudah diperoleh ketika diperlukan. Hal ini 
secara tidak langsung merupakan upaya konservasi masyarakat terhadap sejumlah spesies tumbuhan dalam bentuk pemanfaatan yang lestari, sehingga dapat menjaga populasi spesies tumbuhan tersebut.

\section{Kesimpulan}

1. Jenis tumbuhan sumber pangan yang dimanfaatkan oleh masyarakat sekitar hutan Desa Hli Buei Kecamatan Siding Kabupaten Bengkayang yaitu sebanyak 95 spesies dari 44 famili.

2. Famili terbanyak yang dimanfaatkan masyarakat Desa Hli Buei sebagai pangan adalah dari famili Arecacea dan Zingiberacea masing-masing 7 jenis, Cucurbitaceae dan Poaceae masing-masing 6 jenis, Moraceae dan Solanaceae masing-masing 5 jenis, Euphorbiaceae dan Myrtaceae masing-masing 4 jenis, Anacardiaceae, Phyllanthaceae dan Fabaceae masing-masing 3 jenis.

3. Tumbuhan yang digunakan untuk kegunaan adat sebanyak 10 spesies dari 8 famili. Famili terbanyak yaitu famili Poaceae dan Arecaceae masing-masing 2 spesies, Piperaceae, Musaceae, Dilleniaceae, Rubiaceae, Asparagaceae dan Zingiberaceae masing-masing 1 spesies.

4. Bagian yang digunakan ternyata bagian buah yang lebih banyak dimanfaatkan yaitu sebanyak 36 spesies dan yang terendah pada bagian kulit, kuntum bunga, batang, jantung, teras batang, air , tunas dan umbut masing-masing 1 spesies.
5. Cara pengolahannya ternyata dengan cara dikonsumsi langsung dan dimasak (16 spesies), dimasak (40 spesies) dan dikonsumsi langsung (39 spesies).

6. Kelompok pangan yang paling banyak dimanfaatkan berasal dari buah-buahan yaitu 36 spesies dan yang terendah adalah kelompok sereal 3 spesies. Pola pemanfaatan digunakan sebagai buah-buahan, sayur-sayuran, bumbu, minuman, karbohidrat, dan sereal yaitu diperoleh 98 jenis karena ada tumbuhan yang memiliki 2 jenis pola pemanfaatan.

7. Keberadaan tumbuhan sumber pangan tersebut ternyata terdapat jenis tumbuhan sumber pangan yang mulai sulit ditemui yaitu songk (Pycharrhena cauliflora) dan tumbuhan sumber pangan yang banyak disukai oleh masyarakat desa setempat yaitu banuangk (Manihot utilissima), jamuoi (Syzygium sp), dan't (Cocos nucifera L) karena lebih mudah ditemukan dan dibudidayakan.

\section{Saran}

1. Perlu dilakukan kegiatan pembudidayaan tumbuhan sumber pangan agar tumbuhan sumber pangan tersebut tidak punah, mengingat ada tumbuhan sumber pangan sudah mulai sulit untuk ditemui atau mulai langka. Serta perlu adanya kerja sama antara pemerintah dan masyarakat setempat untuk bersama-sama menjaga kelestarian tumbuhan sumber pangan 
yang terdapat di hutan Desa Hli Buei Kecamatan Siding Kabupaten Bengkayang.

2. Perlu adanya penelitian lanjutan terhadap tumbuhan apakah tumbuhan tersebut dapat dikonsumsi atau tidak dengan cara pengolahan yang praktis, sehingga pemanfaatan tradisional tetap menjadi pilihan utama masyarakat.

\section{UCAPAN TERIMAKASIH}

Saya ucapkan banyak terimakasih kepada Kepala Desa Hli Buei yang telah memberikan izin pelaksanaan penelitian ini. Saya juga mengucapkan terimakasih kepada Pengurus Adat dan Masyarakat Dayak Bidayuh yang bersedia menjadi narasumber pada penelitian ini.

\section{DAFTAR PUSTAKA}

Cahyadi, W. 2005. Analisis dan Aspek Kesehatan Bahan Tambahan Pangan. Bumi Aksara: Jakarta.

Dasman Y, Oramahi dan Lolyta S. 2015. Tumbuhan Sumber Pangan yang Dimanfaatkan oleh Masyarakat Sekitar Hutan Tembawang Desa Nanga Kompi Kecamatan Nanga Sayan Kabupaten Melawi. Jurnal Hutan Lestari. Vol. 3 No. 2 Halaman 332-336.

Flach M, dan F Rumawas. 1996. Plant Resources of South-East Asia. London: Backhuys Publisher.

Grubben GJH dan S Partohardjono. 1996. Plant Resources of SouthEast Asia no 10 Cereals. Prosea: Bogor.

Haryanti ES, Diba F, Wahdina. 2015. Etnobotani Tumbuhan Berguna Oleh Masyarakat Sekitar Kawasan KPH Model Kapuas Hulu (Studi
Kasus Desa Tamao Kecamatan Embaloh Hulu Kalimantan Barat). Jurnal Hutan Lestari. Vol. 3 No. 3 Halaman 434-445.

Hidayat S, Agus H, dan EAM Zuhud. 2010. Kajian Etnobotani Kampung Adat Dukuh Kabupaten Garut, Jawa Barat. Media Konservasi. Vol. 15 No. 3: 139151.

Juliana, Linda R, Mukarlina. 2013. Pemanfaatan Tumbuhan yang Berpotensi Sebagai Sumber Pangan di Gunung Peramas Desa Pangkalan Buton Kecamatan Sukadana Kabupaten Kayong Utara. Jurnal Protobiont. 2 (3) : 117-121.

Martin, GJ. 1998. Etnobotani: Sebuah Manual Pemeliharaan Manusia dan Tumbuhan[diterjemahan oleh Maryati Mohamed]. Edisi bahasa melayu. Malaysia: Natural History Publications (Borneo) Sdn. Bhd.

Nurhajijah, Linda R, Murkalina. 2017. Pemanfaatan Tumbuhan Pangan oleh Suku Dayak Kanayatn di Kecamatan Ngabang Kabupaten Landak. Jurnal Protobiont. Vol. 6 No. 3 Halaman 8-17

Nurhidayah Y, Lovadi I dan Linda R. Tumbuhan Berpotensi Bahan Pangan di Desa Sebangun Kecamatan Sebawi Kabupaten Sambas. Jurnal Protobiont. Vol. 4 No. 1 Halaman 151-159

Saeppudin R. 2005. Etnobotani pada Masyarakata Adat Kasepuan Banten Kidul, Kabupaten Sukabumi,Jawa Barat [Skripsi]. Fakultas Kehutana. Institut Pertanian Bogor. 
Saragih B. 2011. Agribisnis Paradigma Baru Pembangunan Ekonomi Berbasis Pertanian. Bogor: Yayasan Mulia Pesada.

Siemonsma, JS dan K Piluek. 1994. Capsicum L. In: J.M. Poulos (Ed). Prosea, Plant Resources of SouthEast Asia 8, Vegetable. Prosea Foundation. Bogor. P 136-140.

Sugiyono. 2014. Metode Penelitian Manajemen. Bandung: Alfabeta.

Sunarti S, Rugayah dan D Tuite. 2007. Tumbuhan Berpotensi Bahan Pangan di Daerah Cagar Alam Tengkale. Jurnal biodiversitas. Vol. 8 No. 2 Halaman 1-8.
Tatang L, F Victor, S Uwan, MM Sood, A Bayer, D Hasiwan dan Silun. 2000. Kalimantan : Bumi Yang Kaya Makanan. Pontianak : Masyarakat Adat Dayak Mempawah dan Dayak Jalai Bekerjasama Dengan Institut Dayakologi.

Verhejj, EWM dan RE Coronel. 1997. Sumberdaya Nabati Asia Tenggara 2. Penerjemah S. Danimihardja; H. Sutarno; N.W Utami dan D.S.H Hopsen. Gramedia Pustaka Utama: Jakarta.

Weiss, EA. 2002. Spice Crops. Wallingford, England; New York: CABI Publishing. 
Lampiran

Tabel 1. Jenis Tumbuhan Sumber Pangan Yang Dimanfaatkan Oleh Masyarakat Dayak Bidayuh Di Desa Hli Buei Kecamatan Siding Kabupaten Bengkayang (Food Plant Species Used by Dayak Bidayuh Community in Hli Buei Village Siding Subdistrict Bengkayang District)

\begin{tabular}{|c|c|c|c|c|c|c|}
\hline No & Nama Lokal & Nama Ilmiah & Famili & Habitus & Habitat & $\begin{array}{l}\text { Status di Alam } \\
\text { Liar/Budidaya }\end{array}$ \\
\hline 1 & 2 & 3 & 4 & 5 & 6 & 7 \\
\hline 1 & Asom bawang & Mangifera pajang & Anacardiaceae & Pohon & Hutan & Liar dan Budidaya \\
\hline 2 & Baai & Areca catechu $\mathrm{L}$ & Arecaceae & Palem & Perkarangan & Budidaya \\
\hline 3 & Bah & Syzygium polyanthum & Myrtaceae & Pohon & Hutan & Liar \\
\hline 4 & Banuangk & Manihot utilissima & Euphorbiaceae & Herba & Kebun & Budidaya \\
\hline 5 & Bayam & Amaranthus sp & Amaranthaceae & Herba & Ladang & Budidaya \\
\hline 6 & Bieid & Piper betle L & Piperaceae & Liana & Hutan & Liar dan Budidaya \\
\hline 7 & Bih & Dioscorea alata & Dioscoreaceae & Liana & Ladang & Liar dan Budidaya \\
\hline 8 & Bilak kapok & Musa paradisiaca & Musaceae & Perdu & Perkarangan & Budidaya \\
\hline 9 & Biwangk kisai & Allium schoenoprasum & Alliaceae & Herba & Hutan & Budidaya \\
\hline 10 & Blumingk & Baccaurea angulate & Phyllanthaceae & Pohon & Hutan & Liar \\
\hline 11 & Buan't & Dillenia suffruticosa & Dilleniaceae & Perdu & Hutan & Liar \\
\hline 12 & Buduak & Artocarpus integer (Thunb.) Merr & Moraceae & Pohon & Hutan & Liar dan Budidaya \\
\hline 13 & Dan't & Cocos nucifera $\mathrm{L}$ & Arecaceae & Palem & Perkarangan & Liar dan Budidaya \\
\hline 14 & Duk & Colocasia esculanta L & Araceae & Terna & Kebun & Budidaya \\
\hline 15 & Duk awoup & Alocasia $\mathrm{sp}$ & Araceae & Terna & Hutan & Liar \\
\hline 16 & Dungon & Baccaurea macrocarpa & Phyllanthaceae & Pohon & Hutan & Liar \\
\hline 17 & Gayant & Calamus sp & Arecaceae & Herba & Hutan & Liar \\
\hline 18 & Ginjer & Limnocharis flava & Limnocharitaceae & Terna & Hutan & Liar dan Budidaya \\
\hline 19 & Gliei & Ciox lacryma-jobi $\mathrm{L}$ & Poaceae & Perdu & Ladang & Budidaya \\
\hline 20 & Glon't & Gnetum gnemon L & Gnetaceae & Pohon & Hutan & Liar dan Budidaya \\
\hline 21 & Gurinang & Averrhoa bilimbi & Oxalidaceae & Perdu & Perkarangan & Budidaya \\
\hline
\end{tabular}




\begin{tabular}{|c|c|c|}
\hline 22 & Hini'in & Hornstedtia sp \\
\hline 23 & Hlingi & Cucurbita moschata Durch \\
\hline 24 & Hluas & Alpinia galanga $\mathrm{L}$ \\
\hline 25 & Hni'iah & Pometia pinnata Forst \\
\hline 26 & Jagoi & Zea mays $\mathrm{L}$ \\
\hline 27 & Jambu bol & Syzygium malaccense \\
\hline 28 & Jambu minte & Anacardium occidentale $\mathrm{L}$ \\
\hline 29 & Jamuk batuh & Psidium guajava \\
\hline 30 & Jamuk kioei & Bellucia pentamera \\
\hline 31 & Jamuoi & Syzygium sp \\
\hline 32 & Jhemp & Luffa acutangula $(\mathrm{L})$ Roxb \\
\hline 33 & Kedondong & Spondias dulcis \\
\hline 34 & Kemiri & Aleurites moluccanus (L.) Willd \\
\hline 35 & Kia & Luffa aegyptica Mill \\
\hline 36 & Kiliai & Musa balbisiana \\
\hline 37 & Kiloh & Etlingera elatior \\
\hline 38 & Kinih & Gracinia xanthochymus Miq \\
\hline 39 & Kiungk asom & Solanum ferox \\
\hline 40 & Kiungk bilut & Physsalis angulata $\mathrm{L}$ \\
\hline 41 & Kiungk bonyol & Solanum melongena $\mathrm{L}$ \\
\hline 42 & Kiungk kak & Solanum torvum \\
\hline 43 & Klat dhak & Pluerotus ostreatus \\
\hline 44 & Klat jibel & Auricularia auricula-judae \\
\hline 45 & Kliea & Ipomea batatas Lamk \\
\hline 46 & Koko & Theobroma cacao \\
\hline 47 & Komp & Salacca zalacca BI \\
\hline 48 & Kood & Ficus grossulariodes \\
\hline 49 & Koongk & Vatica spp \\
\hline 5 & Kuk & Gracinia mangostana $\mathrm{L}$ \\
\hline
\end{tabular}

$\begin{array}{llll}\text { Zingiberaceae } & \text { Perdu } & \text { Hutan } & \text { Liar } \\ \text { Cucurbitaceae } & \text { Herba } & \text { Ladang } & \text { Budidaya } \\ \text { Zingiberaceae } & \text { Perdu } & \text { Perkarangan } & \text { Liar dan Budidaya } \\ \text { Sapindaceae } & \text { Pohon } & \text { Hutan } & \text { Liar } \\ \text { Poaceae } & \text { Perdu } & \text { Ladang } & \text { Budidaya } \\ \text { Myrtaceae } & \text { Pohon } & \text { Perkarangan } & \text { Budidaya } \\ \text { Anacardiaceae } & \text { Pohon } & \text { Perkarangan } & \text { Budidaya } \\ \text { Myrtaceae } & \text { Perdu } & \text { Perkarangan } & \text { Budidaya } \\ \text { Melastomaceae } & \text { Pohon } & \text { Hutan } & \text { Liar } \\ \text { Myrtaceae } & \text { Pohon } & \text { Perkarangan } & \text { Budidaya } \\ \text { Cucurbitaceae } & \text { Liana } & \text { Ladang } & \text { Budidaya } \\ \text { Anacardiaceae } & \text { Pohon } & \text { Perkarangan } & \text { Budidaya } \\ \text { Euphorbiaceae } & \text { Pohon } & \text { Perkarangan } & \text { Budidaya } \\ \text { Cucurbitaceae } & \text { Liana } & \text { Kebun } & \text { Budidaya } \\ \text { Musaceae } & \text { Perdu } & \text { Hutan } & \text { Liar } \\ \text { Zingiberaceae } & \text { Perdu } & \text { Hutan } & \text { Liar dan Budidaya } \\ \text { Guttiferae } & \text { Pohon } & \text { Hutan } & \text { Liar } \\ \text { Solanaceae } & \text { Herba } & \text { Tampasan/bekas ladang } & \text { Budidaya } \\ \text { Solanaceae } & \text { Herba } & \text { Tampasan/bekas ladang } & \text { Liar } \\ \text { Solanaceae } & \text { Herba } & \text { Ladang } & \text { Budidaya } \\ \text { Solanaceae } & \text { Herba } & \text { Tampasan/bekas ladang } & \text { Liar dan Budidaya } \\ \text { Tricholomataceae } & \text { Herba } & \text { Hutan } & \text { Liar } \\ \text { Auriculariaceae } & \text { Herba } & \text { Hutan } & \text { Liar } \\ \text { Convolvulaceae } & \text { Herba } & \text { Kebun } & \text { Budidaya } \\ \text { Sterculiaceae } & \text { Perdu } & \text { Perkarangan } & \text { Budidaya } \\ \text { Arecaceae } & \text { Palem } & \text { Hutan } & \text { Liar } \\ \text { Moraceae } & \text { Perdu } & \text { Hutan } & \text { Liar } \\ \text { Dipterocarpaceae } & \text { Pohon } & \text { Hutan } & \text { Liar } \\ \text { Guttiferae } & \text { Pohon } & \text { Hutan } & \text { Liar } \\ & & & \end{array}$




\begin{tabular}{|c|c|c|c|c|c|c|}
\hline 51 & Kupi & Coffea $\mathrm{sp}$ & Rubiaceae & Perdu & Perkarangan & Budidaya \\
\hline 52 & Lade & Piper nigrum $\mathrm{L}$ & Piperaceae & Herba & Kebun & Budidaya \\
\hline 53 & Lhamu & Lagenaria siceraria & Cucurbitaceae & Herba & Ladang & Budidaya \\
\hline 54 & Lamut & Nephelium lappaceum $\mathrm{L}$ & Sapindaceae & Pohon & Perkarangan & Budidaya \\
\hline 55 & Lasot & Lansium domesticum Correa & Meliaceae & Pohon & Hutan & Liar dan Budidaya \\
\hline 56 & Liap & Baccaurea motleyana & Phyllanthaceae & Pohon & Hutan & Liar dan Budidaya \\
\hline 57 & Lieai & Durio zibethinus Murr & Bombacaceae & Pohon & Hutan & Liar dan Budidaya \\
\hline 58 & Li'i & Zingiber officinale & Zingiberaceae & Herba & Ladang & Budidaya \\
\hline 59 & Lipi & Elateriospermum tapos & Euphorbiaceae & Pohon & Hutan & Liar \\
\hline 60 & Lisok & Melastoma malabathricum & Melastomataceae & Perdu & Hutan & Liar \\
\hline 61 & Litak mhu & Vigna unguiculata sesquipedalis & Fabaceae & Liana & Kebun & Budidaya \\
\hline 62 & Litak pidang & Psophocarpus tetragonolobus & Fabaceae & Liana & Kebun & Budidaya \\
\hline 63 & Make & Citrullus vulgaris & Cucurbitaceae & Herba & Kebun & Budidaya \\
\hline 64 & Makong & Ipomoea aquatica Forsk & Convolvulaceae & Herba & Hutan & Liar \\
\hline 65 & Manis & Sauropus androgynous & Euphorbiaceae & Perdu & Kebun & Liar dan Budidaya \\
\hline 66 & Mhun & Сucumis sp & Cucurbitaceae & Liana & Ladang & Budidaya \\
\hline 67 & Mmu nipis & Citrus amblycarpa (Hassk) Ochse & Rutaceae & Perdu & Perkarangan & Budidaya \\
\hline 68 & Mieak & Eleiodoxa conferta & Arecaceae & Palem & Hutan & Liar \\
\hline 69 & Milieam & Capsium frutescens & Solanaceae & Herba & Kebun & Liar \\
\hline 70 & Muei & Bambusa sp & Poaceae & Herba & Hutan & Liar dan Budidaya \\
\hline 71 & Naka & Artocarpus heterophyllus Lamk & Moraceae & Pohon & Perkarangan & Budidaya \\
\hline 72 & Naka bhane & Anonna muricata $\mathrm{L}$ & Anonnaceae & Perdu & Perkarangan & Budidaya \\
\hline 73 & Nanas & Ananas comosus $\mathrm{L}$ & Bromeliaceae & Terna & Kebun & Budidaya \\
\hline 74 & Nghuei & Ocimum basilicum $\mathrm{L}$ & Lamiaceae & Herba & Tampasan/bekas ladang & Liar \\
\hline 75 & Nyuak & Arenga pinnata Merr & Arecaceae & Palem & Hutan & Liar \\
\hline 76 & Pap & Asplenium nidus $\mathrm{L}$ & Aspleniaceae & Epifit & Hutan & Liar \\
\hline 77 & Patek & Carica papaya $\mathrm{L}$ & Caricaceae & Perdu & Kebun & Budidaya \\
\hline 78 & Pidiei & Oryza sativa $\mathrm{L}$ & Poaceae & Herba & Ladang & Budidaya \\
\hline 79 & Pikies & Stenochlena polustris & Denstaediticeae & Herba & Hutan & Liar \\
\hline
\end{tabular}




\begin{tabular}{|c|c|c|c|c|c|c|}
\hline 80 & Pikuh & Diplazium esculentum & Athyriaceae & Herba & Hutan & Liar \\
\hline 81 & Pikuh jingk & Polypodium verrucosum & Polypodiaceae & Herba & Hutan & Liar \\
\hline 82 & Pluntan & Artocarpus sericicarpus & Moraceae & Pohon & Hutan & Liar \\
\hline 83 & Puoes & Etlingera $\mathrm{sp}$ & Zingiberaceae & Perdu & Hutan & Liar \\
\hline 84 & Sabik & Brassica $\mathrm{sp}$ & Brassicaceae & Herba & Ladang & Budidaya \\
\hline 85 & Sagu & Metroxylon sagu Rottbell & Arecaceae & Palem & Hutan & Liar \\
\hline 86 & Satol & Sandoricum keotjape Merr & Meliaceae & Pohon & Hutan & Liar \\
\hline 87 & Simud & Averrhoa carambola $\mathrm{L}$ & Oxalidaceae & Perdu & Perkarangan & Budidaya \\
\hline 88 & Sikual & Kaempferia galangal & Zingiberaceae & Herba & Kebun & Budidaya \\
\hline 89 & Siliei & Cymbopongon citratus & Poaceae & Herba & Kebun & Budidaya \\
\hline 90 & Songk & Pycharrhena cauliflora & Manispermaceae & Pohon & Hutan & Liar \\
\hline 91 & Taop & Artocarpus elasticus Reinw. ex BI. & Moraceae & Pohon & Hutan & Liar \\
\hline 92 & Tayongk & Pithecolobium lobatum Benth & Leguminaceae & Pohon & Hutan & Liar \\
\hline 93 & Tibuh & Saccharum officinarum & Poaceae & Perdu & Kebun & Budidaya \\
\hline 94 & Thieah & Parkia speciosa Hassk & Fabaceae & Pohon & Kebun & Liar dan Budidaya \\
\hline 95 & Timuk & Curcuma domestica & Zingiberaceae & Herba & Kebun & Budidava \\
\hline
\end{tabular}

